Sains Malaysiana 48(8)(2019): 1713-1719

http://dx.doi.org/10.17576/jsm-2019-4808-17

\title{
The Sella Turcica Dimensions in 12-Year-Old Southern Chinese: A Cross-Sectional Study
}

(Dimensi Sella Turcica pada Populasi Berusia 12 tahun di Selatan China: Suatu Kajian Keratan Rentas)

\author{
MOHD ZAMBri MOHAMED MAKHBUL*, WAN NURAZREENA WAN HASSAN \& RicKY Wing KiT WonG
}

\begin{abstract}
The objective of the study was to measure the dimensions of the sella turcica in southern Chinese population. This retrospective study measured dimensions of sella turcica from lateral cephalometric radiographs obtained from the University of Hong Kong research database with a total of 582 (277females and 305 males) 12-year-old southern Chinese children, who were randomly selected from schools in Hong Kong. Measurements were made using ImageJ (V1.45s) software for Windows with Frankfurt plane as the horizontal reference direction. Dimensions between genders were compared using Student's t-tests. The current study found the antero-posterior length and width were $9.13 \mathrm{~mm}$ (SD 2.05) and $9.76 \mathrm{~mm}$ (SD 1.54), respectively. The sella was highest posteriorly (7.97 mm; SD $1.75 \mathrm{~mm}$ ) and shortest anteriorly $(7.56 \mathrm{~mm} ; \mathrm{SD}$ 1.42). Sella height anterior, sella height median and sella area were greater $(\mathrm{p}<0.05)$ in females by 0.53 $\mathrm{mm}, 0.24 \mathrm{~mm}$ and $3.48 \mathrm{~mm}^{2}$, respectively. In conclusion, this study provides the reference parameters for the dimensions of sella turcica for the Southern Chinese population.
\end{abstract}

Keywords: Children; Chinese; radiographic film; sella turcica

ABSTRAK

Objektif penyelidikan ini adalah untuk mengukur dimensi sella turcica bagi penduduk di selatan China. Kajian retrospektif ini mengukur dimensi sella turcica melalui radiografi sefalometrik lateral yang diperoleh daripada data penyelidikan Universiti Hong Kong iaitu sebanyak 582 (277 perempuan dan 305 lelaki) kanak-kanak 12 tahun, telah dipilih secara rawak dari sekolah-sekolah di Hong Kong. Pengukuran dibuat dengan menggunakan perisian ImageJ (VI.45s) untuk sistem operasi Windows serta menggunakan planar Frankfurt sebagai rujukan mendatar. Dimensi antara jantina dibandingkan dengan menggunakan ujian t berpasangan. Kajian ini mendapati panjang dan lebar antero-posterior masing-masing adalah $9.13 \mathrm{~mm}$ (SD 2.05) dan $9.76 \mathrm{~mm}$ (SD 1.54). Sella adalah paling tinggi di posterior (7.97 mm; SD $1.75 \mathrm{~mm}$ ) dan paling pendek di anterior (7.56 mm; SD 1.42). Ketinggian anterior Sella, ketinggian median sella dan kawasan sella adalah lebih besar ( $\mathrm{p}<0.05$ ) dalam kalangan perempuan, iaitu masing-masing adalah $0.53 \mathrm{~mm}, 0.24 \mathrm{~mm}$ dan $3.48 \mathrm{~mm}^{2}$. Kesimpulannya, kajian ini menyediakan parameter rujukan bagi dimensi sella turcica untuk penduduk di selatan China.

Kata kunci: China; filem radiografik; kanak-kanak; sella turcica

\section{INTRODUCTION}

Sella turcica is a relatively small structure of the sphenoid bone within the middle cranial fossa and contains the pituitary gland. The normal radiographic anatomy of sella turcica is central for early identification of pathological conditions (Alkofide 2007; Feldkamp et al. 1999; Friedland \& Meazzini 1996). Changes in the shape of the sella turcica can be due to pathology or abnormality in the pituitary gland such as the interruption in secretion of glandular hormones; prolactin, growth hormones, thyroid stimulating hormone, follicular stimulating hormone (Elster 1993a,1993b; Pisaneschi \& Kapoor 2005). Acromegaly or gigantism, Cushing disease, hyperthyroidism, amenorrhea and galactorrhea, and menstrual disturbances are problems that manifest from hormonal disorders originating from the pituitary gland (Elster 1993a, 1993b).
Patients with syndromic conditions such as Down syndrome (Russell \& Kjaer 1999), Williams syndrome (Axelsson et al. 2004), Seckel syndrome (Kjaer et al. 2001) and lumbosacral myelomeningocele (Kjaer et al. 1999) have also shown differences in the shape of sella. This indicates that the shape of sella turcica may be considered a diagnostic marker for certain syndromic condition. In addition, the morphology of the hypophysis, the venous sinuses which connect the cavernous sinuses crossing the midline and situated along the anterior, posterior or inferior surface of the pituitary gland may also influence the shape of sella (Renn \& Rhoton 1975).

The morphology of sella is also affected by the presence of osseous bridges in between the clinoid processes and it is relative to the neighboring internal carotid artery (Inoue et al. 1990). The frequency of the 
prevalence of a sella turcica bridge in radiographic and anatomical studies is 1.75 to $6 \%$ in a normal population (Becktor et al. 2000). Calcification and bridging of sella turcica have been suggested as diagnostic predictors for craniofacial and dental anomalies. Patients with severe craniofacial anomalies who require combined surgicalorthodontic treatment are found to have higher frequency of sella turcica bridging compared to those patients requiring only orthodontics (Becktor et al. 2000; Jones et al. 2005). Prevalence of sella turcica bridge is significantly higher in patients with skeletal Class III discrepancy, which present a significantly larger mandible in relation to the maxilla (Meyer-Marcotty et al. 2010). Skeletal Class III patients may also have larger sella turcica (Shrestha et al. 2018). The sella turcica bridge is also associated with higher frequencies of dental transpositions (Leonardi et al. 2011), impacted canines (Ali et al. 2014; Scribante et al. 2017) and hypo- and hyperdontia (Scribante et al. 2017).

The radiographic image of the sella turcica may be taken as part of diagnostic investigations of other craniofacial structures. For example, the center of the sella turcica is a cephalometric landmark used as a reference for the diagnosis of craniofacial relationships. Thus, clinicians who routinely take the image of sella turcica for radiographic investigations should be aware of its normal dimensions to enable early referral when abnormalities are suspected. The dimensions of sella have been described for different populations including Americans, Saudis and Pakistans (Alkofide 2007; Ouaknine \& Hardy 1987; Shah et al. 2011). In addition, a previous study reported that the average shape of sella turcica was slightly different between males and females especially at the posterior part of the outline (Andredaki et al. 2007).

Currently, there is no information on the dimensions of sella turcica in the Southern Chinese population. According to Cooke and Wei (1988), Southern Chinese have marked physical and cultural differences from the Northern Chinese. The Southern Chinese in Hong Kong generally originate from Guangdong, the southern province of China. They have a smaller stature than the taller Northern Chinese (Cooke \& Wei 1988). They mainly speak in Cantonese and have rice-based diet in comparison to the mandarin speaking Northern Chinese who mainly consume wheat-based diet (Cooke \& Wei 1988). Thus, such anthropological differences suggest that there are potential norms specific to Southern Chinese.

The aim of this study was to quantitatively measure the dimensions of sella turcica in Southern Chinese children. The findings of this study may be useful as a reference to identify potential pathological conditions when abnormality in the dimension of sella is suspected.

\section{MATERIALS AND METHODS}

\section{STUDY DESIGN}

This was a retrospective cross-sectional study using lateral cephalometric radiographs obtained from the research data records of the Faculty of Dentistry of the University of Hong Kong.

\section{SETTING}

Data records were obtained from an oral health survey performed in 1984 to 1985 at the Department of Orthodontics and Paediatric Dentistry of the University of Hong Kong (Cooke \& Wei 1988). Briefly, the epidemiological study was conducted in Hong Kong SAR, China among 12-year-old children. Ten percent of all secondary schools in Hong Kong SAR were randomly selected and children within each selected schools were invited to participate. Written informed consents were obtained from parents and children who agreed to participate.

\section{PARTICIPANTS}

The inclusion criteria for the lateral cephalometric radiographs were films labelled with southern Chinese ethnicity and 12-year-old in age with clear images of sella turcica. The exclusion criteria were non-Southern Chinese children and samples with any medical history of craniofacial surgery, trauma, syndromes, cleft lip or palate.

\section{MEASUREMENTS AND ASSESSMENT OF METHOD ERRORS}

Each radiograph was traced by a single operator (MZMM) using an acetate paper in a dark room. The traced radiographs were scanned at a resolution of $200 \mathrm{dpi}$ with a reference ruler to scale the image at 1:1 to eliminate the magnification error.

The outline of the sella turcica was traced between the point tuberculum sella (TS) and posterior clinoid (PClin) using the Frankfort horizontal plane (FH) as the horizontal reference direction. Other points identified to facilitate measurements of linear dimensions were the sella posterior (SP), sella anterior (SA), sella floor (SF) and median point of the sella turcica (SM) (Figure 1).

The dimensions of the sella turcica were measured using image ImageJ (V1.45s) for Windows Software, accurate to two decimal points. The area was automatically calculated by the software after the outlines were traced. To assess intra-examiner repeatability, 10 radiographs were randomly selected, retraced and rescanned on separate occasions after a two-week interval. The random error was calculated using Dahlberg's formula and paired t-test (Houston 1983). Error variance exceeding $10 \%$ was considered unacceptable (Houston 1983).

\section{VARIABLES}

The linear dimensions were measured according to the following definitions (Andredaki et al. 2007):

Sella width (SW): The largest antero-posterior dimension, as measured parallel to the FH, from SP to SA; Sella length (SL): The distance from TS to PClin; Sella height Anterior (SHA): The vertical distance, as measured perpendicular to 


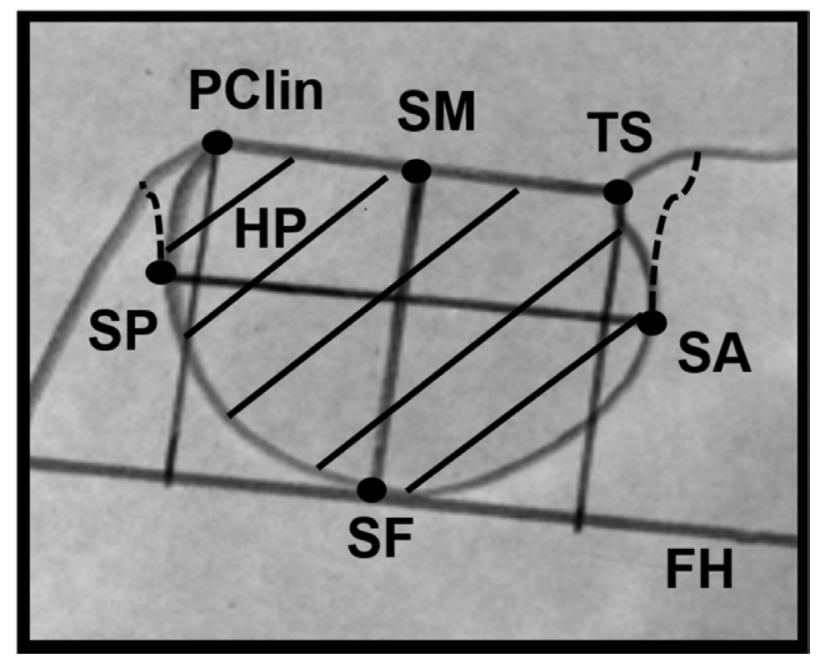

FIGURE 1. Landmarks for the sella dimensions. The sella turcica width (SW) is the largest antero-posterior dimension and parallel to Frankfort horizontal (FH) plane, as measured from posterior point of the sella turcica (SP) to anterior point of the sella turcica (SA); sella turcica length (SL) is the distance from the tuberculum of the sella turcica (TS) to the most anterior point of the posterior clinoid process (PClin); sella turcica anterior (SHA) is the vertical distance, as measured perpendicular to the FH plane from TS; sella turcica posterior (SHP) is the vertical distance, as measured perpendicular to FH plane, from PClin; sella turcica median (SHM) is the vertical distance, as measured perpendicular to the FH plane, from the SF to a point midway between PClin and TS (SM); and sella turcica area

(SAr) is the area included by the outline of the sella and capped by a line joining PClin to TS

the FH, TS to SF; Sella height posterior (SHP): The vertical distance, as measured perpendicular to the $\mathrm{FH}$, from PClin to SF; and Sella height median (SHM): The vertical distance, as measured perpendicular to $\mathrm{FH}$, from $\mathrm{SF}$ to $\mathrm{SM}$, which is a point midway between PClin and TS.

In addition, the Sella area (SAr) was also measured. This was defined as the area included by the outline of the sella and capped by a line joining PClin to TS.

\section{STUDY SIZE AND BIAS}

As this was a retrospective study, bias was minimized by including all lateral cephalometric radiographs from the research data records that met the inclusion criteria. It was not advisable prospectively to recruit samples as it would impose the risk of radiographic radiation to subjects.

\section{QUANTITATIVE VARIABLES}

The dimensions of sella were compared between genders (Andredaki et al. 2007).

\section{STATISTICAL ANALYSIS}

SPSS (version 20.0.0) was used for analysis. Student's t-test for independent data, with a significance level of $5 \%$ was used to compare the statistical differences between genders.

\section{ETHICAL APPROVAL}

This was a retrospective study which measured lateral cephalometric radiographs with no personal identifications. Therefore, ethical approval was not applied.

\section{RESULTS AND DISCUSSION}

\section{NORMATIVE DATA FOR SOUTHERN CHINESE CHILDREN}

Lateral cephalometric radiographs of 582 subjects (277 females and 305 males) were included in this study. This study is the first study to quantify the dimensions of sella turcica in 12-year-old southern Chinese children. The findings of this study can be used as normative values for 12-year-old southern Chinese children.

Pathology in the pituitary gland may exist without osseous manifestations (Andredaki et al. 2007). Thus, any abnormality detected in the dimensions of sella turcica may require early referral for the benefit of the patient. Such incidental findings noted by the clinician may indicate further investigation of undiagnosed or subclinical conditions (Elster 1993; Friedland \& Meazzini 1996).

\section{THE SELLA TURCICA DIMENSIONS OF SOUTHERN CHINESE CHILDREN}

The morphological variations in the shape of the sella have been classified as normal or having an oblique anterior wall, double contoured sella, sella turcica bridge, irregularity (notching) in the posterior part of the sella, and pyramidal shape of the dorsum of the sella (Alkofide 2007; Axelsson et al. 2004). In this study, the shape of sella turcica was not taken into account. Instead, the study concentrated on the dimensions of sella turcica which is independent of variability in the morphology of the sella that made classification challenging.

Table 1 shows that the measurements errors for sella dimensions were considered minor as they ranged within 
$\pm 0.20 \mathrm{~mm}$ for linear measurements and $0.35 \mathrm{~mm}^{2}$ for the sella area. Paired t-test showed no systematic errors between duplicates measurements of the variables $(p>0.05)$. The intra-examiner random errors were acceptable (Houston 1983), ranging from $0.42 \%$ to $4.15 \%$.

The mean dimensions of the sella turcica found in this study were different with other populations (Abu Ghaida et al. 2017; Alkofide 2007; Ouaknine \& Hardy 1987; Shah et al. 2011). The SW of southern Chinese $(9.76 \mathrm{~mm})$ was smaller than American populations (12.0 mm) (Ouaknine \& Hardy 1987 ) but larger than Jordanian adolescents $(8.51 \mathrm{~mm})$ (Abu Ghaida et al. 2017). The SL $(9.13 \mathrm{~mm})$ and SHM $(7.78 \mathrm{~mm})$ of Southern Chinese were larger than Americans (8.0 and 6.0 , respectively) (Ouaknine \& Hardy 1987) and Jordanian adolescents ( $7.44 \mathrm{~mm}$ and $6.16 \mathrm{~mm}$, respectively) (Abu Ghaida et al. 2017) but smaller than Pakistan populations (11.3 $\mathrm{mm}$ and $9.9 \mathrm{~mm}$, respectively) (Shah et al. 2011). The SL of southern Chinese was similar to northern Indians (9.15 mm) (Gargi et al. 2019) but smaller than Turkish children (8.10 mm) (Magat \& Ozcan Sener 2018) and Saudi populations, which was found to be $10.7 \mathrm{~mm}$ in females and $11.0 \mathrm{~mm}$ in males (Alkofide 2007). The SAr of Southern Chinese children $\left(64.92 \mathrm{~mm}^{2}\right)$ is also larger than Jordanian adolescents $\left(39.03 \mathrm{~mm}^{2}\right.$ ) (Abu Ghaida et al. 2017). This suggests that there are population specific dimensions of the sella turcica. The differences in the dimensions of the sella turcica between populations can be attributed to ethnicity, genetic makeup, and environmental factors that may be present between different populations (Shrestha et al. 2018).

\section{GENDER DIFFERENCES OF THE SELLA DIMENSIONS}

Lateral cephalometric radiographs of 277 females and 305 males were included in the study. Table 2 shows the dimensions of sella turcica for 12-years-old southern Chinese schoolchildren. The SW was found to be $9.76 \mathrm{~mm}$ (SD 0.54) and the SL was $9.13 \mathrm{~mm}$ (SD 2.05). There was a reduction in the height of sella from $7.97 \mathrm{~mm}$ (SD 1.74) at the posterior SHP, to $7.78 \mathrm{~mm}$ (SD 1.23) at the median i.e. SHM and $7.56 \mathrm{~mm}$ (SD 1.42) at the anterior part of the sella SHA. The SAr was $64.92 \mathrm{~mm}^{2}$ (SD 16.12).

Independent t-test by Levene's test between the genders showed that apart from $\mathrm{SW}$, equal variances were not assumed. SHA and SHM measurements for females were statistically significantly higher than males with mean differences of $0.53 \mathrm{~mm}$ and $0.24 \mathrm{~mm}$, respectively. The SAr was also statistically significantly higher in females than males by $3.48 \mathrm{~mm}^{2}$ (Table 3 ).

The current study found significant differences in the dimensions of sella turcica between genders, particularly for SHA and SHM. Southern Chinese females had longer SHA by $0.53 \mathrm{~mm}$ and longer SHM by $0.24 \mathrm{~mm}$ compared to males. Andredaki et al. (2007) similarly found that females had longer SHA by $0.3 \mathrm{~mm}$. The SAr of southern Chinese was also found to be larger in females by $3.48 \mathrm{~mm}^{2}$ compared to males. In contrast, studies in Ohio, Pakistan, India and Turkey found no significant differences in the sella dimensions between genders (Chaitanya et al. 2018; Gargi et al. 2019; Israel 1970; Magat \& Ozcan Sener 2018; Shah et al. 2011). However, the sella height in northern Indian males were larger than their females (Gargi et al. 2019). In a study on Jordanian sample, there were no differences between adolescent males and females, but adult males had larger sella dimensions than adult females except for the sella height dimension (Abu Ghaida et al. 2017). It may be possible that the differences in the dimensions between genders found in this study were

TABLE 1. Means of replicate tracings measurements of 10 radiographs within 2 weeks interval and calculations of the intra-examiner's method error and reproducibility

\begin{tabular}{|c|c|c|c|c|c|c|c|c|}
\hline \multirow{2}{*}{ Variables } & \multicolumn{2}{|c|}{$\mathrm{T} 1$} & \multicolumn{2}{|c|}{$\mathrm{T} 2$} & \multirow{2}{*}{$\begin{array}{c}\text { Mean } \\
\text { difference }\end{array}$} & \multirow{2}{*}{ SD } & \multirow{2}{*}{$\begin{array}{l}\text { Dahlberg's } \\
\text { error variance }\end{array}$} & \multirow{2}{*}{$\begin{array}{c}\text { t-test } \\
\mathrm{p} \text {-value }\end{array}$} \\
\hline & Mean & SD & Mean & SD & & & & \\
\hline Sella Width (SW) & 10.26 & 2.02 & 10.40 & 2.16 & -0.13 & 0.60 & 0.42 & 0.514 \\
\hline Sella Length (SL) & 10.40 & 2.31 & 10.57 & 2.02 & -0.20 & 0.84 & 0.60 & 0.467 \\
\hline Sella Height Posterior (SHP) & 8.03 & 1.22 & 7.92 & 1.34 & 0.11 & 0.73 & 0.52 & 0.658 \\
\hline Sella Height Anterior (SHA) & 6.81 & 0.91 & 6.73 & 1.03 & 0.09 & 1.02 & 0.72 & 0.799 \\
\hline Sella Height Median (SHM) & 7.43 & 0.66 & 7.38 & 0.85 & 0.05 & 0.67 & 0.47 & 0.815 \\
\hline Sella Area (SAr) & 62.23 & 12.43 & 61.88 & 13.91 & 0.35 & 5.87 & 4.15 & 0.854 \\
\hline
\end{tabular}

T1, time 1 (baseline); T2, time 2 (after 2 weeks); SD, standard deviation; Method error calculated by Dahlberg formula; *significant at $p<0.05$

TABLE 2. Sella turcica dimensions (in mm) of 12-year-old Southern Chinese children

\begin{tabular}{lccccc}
\hline Variables & $\mathrm{N}$ & Mean & SD & Std. Error of mean & Minimum \\
\hline Sella width (SW) & 582 & 9.76 & 1.54 & 0.06 & 3.34 \\
Sella length (SL) & 582 & 9.13 & 2.05 & 0.08 & 2.84 \\
Sella height posterior (SHP) & 582 & 7.97 & 1.75 & 0.07 & 0.09 \\
Sella height anterior (SHA) & 582 & 7.56 & 1.42 & 0.06 & 3.47 \\
Sella height median (SHM) & 582 & 7.78 & 1.23 & 0.05 & 3.39 \\
Sella area (SAr) & 582 & 64.92 & 16.12 & 0.67 & 12.74 \\
\hline
\end{tabular}


TABLE 3. Sella turcica dimension (in $\mathrm{mm}$ ) of males and females in 12-year-old Southern Chinese children

\begin{tabular}{|c|c|c|c|c|c|c|c|c|c|c|c|}
\hline \multirow{2}{*}{ Variables } & \multirow{2}{*}{ Sex } & \multirow{2}{*}{$\mathrm{N}$} & \multirow{2}{*}{ Mean } & \multirow{2}{*}{ SD } & \multirow{2}{*}{$\begin{array}{c}\text { Std. Error } \\
\text { Mean }\end{array}$} & \multirow{2}{*}{ Min. } & \multirow{2}{*}{ Max. } & \multirow{2}{*}{$\begin{array}{c}\text { Mean } \\
\text { difference }\end{array}$} & \multirow{2}{*}{$\begin{array}{c}\mathrm{p} \\
\text { value }\end{array}$} & \multicolumn{2}{|c|}{$95 \% \mathrm{CI}$} \\
\hline & & & & & & & & & & Lower & Upper \\
\hline \multirow[t]{2}{*}{ Sella width (SW) } & M & 305 & 9.70 & 1.64 & 0.09 & 3.34 & 14.87 & \multirow[t]{2}{*}{-0.14} & \multirow[t]{2}{*}{0.27} & \multirow[t]{2}{*}{-0.39} & \multirow[t]{2}{*}{0.11} \\
\hline & $\mathrm{F}$ & 277 & 9.84 & 1.42 & 0.09 & 6.19 & 15.69 & & & & \\
\hline \multirow[t]{2}{*}{ Sella length (SL) } & M & 305 & 9.20 & 2.12 & 0.12 & 2.84 & 15.31 & \multirow[t]{2}{*}{0.15} & \multirow[t]{2}{*}{0.38} & \multirow[t]{2}{*}{-0.18} & \multirow[t]{2}{*}{0.48} \\
\hline & $\mathrm{F}$ & 277 & 9.05 & 1.96 & 0.12 & 4.05 & 15.69 & & & & \\
\hline \multirow[t]{2}{*}{ Sella height posterior (SHP) } & M & 305 & 7.99 & 1.84 & 0.11 & 0.09 & 11.78 & \multirow[t]{2}{*}{0.04} & \multirow[t]{2}{*}{0.79} & \multirow[t]{2}{*}{-0.25} & \multirow[t]{2}{*}{0.32} \\
\hline & $\mathrm{F}$ & 277 & 7.95 & 1.65 & 0.10 & 1.34 & 12.74 & & & & \\
\hline \multirow[t]{2}{*}{ Sella height anterior (SHA) } & M & 305 & 7.31 & 1.42 & 0.08 & 3.47 & 12.45 & \multirow[t]{2}{*}{-0.53} & \multirow[t]{2}{*}{$0.00 *$} & \multirow[t]{2}{*}{-0.75} & \multirow[t]{2}{*}{-0.30} \\
\hline & $\mathrm{F}$ & 277 & 7.83 & 1.37 & 0.08 & 4.03 & 12.06 & & & & \\
\hline \multirow[t]{2}{*}{ Sella height median (SHM) } & M & 305 & 7.66 & 1.26 & 0.07 & 3.39 & 11.18 & \multirow[t]{2}{*}{-0.24} & \multirow[t]{2}{*}{$0.02 *$} & \multirow[t]{2}{*}{-0.44} & \multirow[t]{2}{*}{-0.04} \\
\hline & $\mathrm{F}$ & 277 & 7.91 & 1.19 & 0.07 & 3.99 & 11.29 & & & & \\
\hline Sella area (SAr) & M & 305 & 63.26 & 16.61 & 0.95 & 20.81 & 106.90 & -3.48 & $0.01 *$ & -6.10 & -0.87 \\
\hline & $\mathrm{F}$ & 277 & 66.74 & 15.38 & 0.922 & 29.00 & 126.19 & & & & \\
\hline
\end{tabular}

$\mathrm{SD}$, standard deviation; CI, Confidence interval; *Statistically significant different between genders, as determined by independent t-test, $p<0.05$ and $95 \%$ confidence

attributed by the stage of growth of the population. The mean peak height velocity has been found to be earlier in females at 12.1 years compared to males at 13.7 years (Granados et al. 2015). Considering that the females of the current study may be undergoing a peak in their growth compared to the males, the size of their sella may have been affected by the active secretion of the growth hormone.

\section{LIMITATIONS OF THE STUDY}

This retrospective study analyzed the dimensions of sella turcica in southern Chinese population based on a large sample of subjects using the two-dimensional lateral cephalometric radiographs.

The cephalometric image was in two-dimensions (2D), which is not representative of the three-dimensional (3D) structure of the sella turcica. Cone beam computed tomography $(\mathrm{CBCT})$ is more accurate and reliable compared to lateral cephalogram because the skull orientation in CBCT is not affected by linear measurements (Adams et al. 2004; Berco et al.2009). The anatomical structure of sella turcica can be studied more effectively in СBCT images (Yasa et al. 2017). Nonetheless, the dimensions reported in this study can still be used for reference as current softwares are able to generate lateral cephalograms from CBCT or MRI datasets. Measurements made on conventional lateral cephalograms were comparable with those generated from CBCT or MRI datasets (Heil et al. 2017; Navarro et al. 2013) though clinicians need to be mindful of the variations between methods (Smektala et al. 2014).

Discrepancies in measurements of past reports have been accounted to the use of different landmarks, radiographic techniques, and degree of radiographic enlargement (Axelsson et al. 2004). To overcome this, this study used $\mathrm{FH}$ as a reference plane to measure the dimensions of sella turcica because the antero-posterior and vertical measurements are independent from the shape of the sella (Silverman 1957). In addition, prior to analysis, the scale was confirmed to be $1: 1$, thus compensation for magnification error (Houston 1983) was not required.

\section{CONCLUSION}

The findings of this study are useful as normative reference for southern Chinese children. The mean dimensions of sella turcica in 12-year-old Southern Chinese population were between $7.56 \mathrm{~mm}$ to $9.97 \mathrm{~mm}$ with an area of 64.92 $\mathrm{mm}^{2}$. Gender differences were noted for the sella height anterior, sella height median and sella area, with females showing larger dimensions.

\section{ACKNOWLEDGEMENTS}

Support was obtained by a grant from the Research Grants Council of the Hong Kong Special Administrative Region, China. Special thanks Yuen Sze Wan for helpful comments.

\section{REFERENCES}

Abu Ghaida, J.H., Mistareehi, A.J., Mustafa, A.G., Mistarihi, S.M. \& Ghozlan, H.H. 2017. The normal dimensions of the sella turcica in Jordanians: A study on lateral cephalograms. Folia Morphol. (Warsz) 76(1): 1-9.

Adams, G.L., Gansky, S.A., Miller, A.J., Harrell Jr., W.E. \& Hatcher, D.C. 2004. Comparison between traditional 2-dimensional cephalometry and a 3-dimensional approach on human dry skulls. Am. J. Orthod. Dentofacial Orthop. 126(4): 397-409.

Ali, B., Shaikh, A. \& Fida, M. 2014. Association between sella turcica bridging and palatal canine impaction. Am.J. Orthod. Dentofacial Orthop. 146(4): 437-441.

Alkofide, E.A. 2007. The shape and size of the sella turcica in skeletal Class I, Class II, and Class III Saudi subjects. Eur. J. Orthod. 29(5): 457-463.

Andredaki, M., Koumantanou,A., Dorotheou, D. \& Halazonetis, D.J. 2007. A cephalometric morphometric study of the sella turcica. Eur. J. Orthod. 29(5): 449-456.

Axelsson, S., Storhaug, K. \& Kjaer, I. 2004. Post-natal size and morphology of the sella turcica. Longitudinal cephalometric 
standards for Norwegians between 6 and 21 years of age. Eur. J. Orthod. 26(6): 597-604.

Becktor, J.P., Einersen, S. \& Kjaer, I. 2000. A sella turcica bridge in subjects with severe craniofacial deviations. Eur.J. Orthod. 22(1): 69-74.

Berco, M., Rigali Jr., P.H., Miner, R.M., DeLuca, S., Anderson, N.K. \& Will, L.A. 2009. Accuracy and reliability of linear cephalometric measurements from cone-beam computed tomography scans of a dry human skull. Am. J. Orthod. Dentofacial Orthop. 136(1): 17.e1-17.e9.

Chaitanya, B., Pai, K.M. \& Chhaparwal, Y. 2018. Evaluation of the effect of age, gender, and skeletal class on the dimensions of sella turcica using lateral cephalogram. Contemp. Clin. Dent. 9(2):195-199.

Cooke, M.S. \& Wei, S.H. 1988. Cephalometric standards for the Southern Chinese. Eur. J. Orthod. 10(3): 264-272.

Elster, A.D. 1993a. Imaging of the sella: Anatomy and pathology. Semin. Ultrasound CT MR 14(3): 182-194.

Elster, A.D. 1993b. Modern imaging of the pituitary. Radiology 187(1): 1-14.

Feldkamp, J., Santen, R., Harms, E., Aulich, A., Modder, U. \& Scherbaum, W.A. 1999. Incidentally discovered pituitary lesions: High frequency of macroadenomas and hormonesecreting adenomas - Results of a prospective study. Clin. Endocrinol. (Oxf) 51(1): 109-113.

Friedland, B. \& Meazzini, M.C. 1996. Incidental finding of an enlarged sella turcica on a lateral cephalogram. Am.J. Orthod. Dentofacial Orthop. 110(5): 508-512.

Gargi, V., Ravi Prakash, S.M., Nagaraju, K., Malik, S., Goel, S. \& Gupta, S. 2019. Radiological analysis of the sella turcica and its correlations with body mass index in a North Indian population. Oral Radiol. 35(2): 184-188.

Granados, A., Gebremariam, A. \& Lee, J.M. 2015. Relationship between timing of peak height velocity and pubertal staging in boys and girls. J. Clin. Res. Pediatr. Endocrinol. 7(3): 235-237.

Heil, A., Lazo Gonzalez, E., Hilgenfeld, T., Kickingereder, P., Bendszus, M., Heiland, S., Ozga, A.K., Sommer, A., Lux, C.J. \& Zingler, S. 2017. Lateral cephalometric analysis for treatment planning in orthodontics based on MRI compared with radiographs: A feasibility study in children and adolescents. PLOS ONE 12(3): e0174524.

Houston, W.J. 1983. The analysis of errors in orthodontic measurements. Am. J. Orthod. 83(5): 382-390.

Inoue, T., Rhoton Jr., A.L., Theele, D. \& Barry, M.E. 1990. Surgical approaches to the cavernous sinus: A microsurgical study. Neurosurgery 26(6): 903-932.

Israel, H. 1970. Continuing growth in sella turcica with age. Am. J. Roentgenol. Radium Ther. Nucl. Med. 108(3): 516-527.

Jones, R.M., Faqir, A., Millett, D.T., Moos, K.F. \& McHugh, S. 2005. Bridging and dimensions of sella turcica in subjects treated by surgical-orthodontic means or orthodontics only. Angle Orthod. 75(5): 714-718.

Kjaer, I., Becktor, K.B., Lisson, J., Gormsen, C. \& Russell, B.G. 2001. Face, palate, and craniofacial morphology in patients with a solitary median maxillary central incisor. Eur. J. Orthod. 23(1): 63-73.

Kjaer, K.W., Hansen, B.F., Keeling, J.W., Nolting, D. \& Kjaer, I. 1999. Malformations of cranial base structures and pituitary gland in prenatal Meckel syndrome. APMIS 107(10): 937944.

Leonardi, R.,Farella, M. \& Cobourne, M.T. 2011. An association between sella turcica bridging and dental transposition. Eur. J. Orthod. 33(4): 461-465.
Magat, G. \& Ozcan Sener, S. 2018. Morphometric analysis of the sella turcica in Turkish individuals with different dentofacial skeletal patterns. Folia Morphol. (Warsz) 77(3): 543-550.

Meyer-Marcotty, P., Reuther, T. \& Stellzig-Eisenhauer, A. 2010. Bridging of the sella turcica in skeletal Class III subjects. Eur. J. Orthod. 32(2): 148-153.

Navarro Rde, L., Oltramari-Navarro, P.V., Fernandes, T.M., Oliveira, G.F., Conti, A.C., Almeida, M.R. \& de Almeida, R.R. 2013. Comparison of manual, digital and lateral CBCT cephalometric analyses. J. Appl. Oral Sci. 21(2): 167-176.

Ouaknine, G.E. \& Hardy, J. 1987. Microsurgical anatomy of the pituitary gland and the sellar region. 1 . The pituitary gland. Am. Surg. 53(5): 285-290.

Pisaneschi, M. \& Kapoor, G. 2005. Imaging the sella and parasellar region. Neuroimaging Clin.N.Am. 15(1): 203-219.

Renn, W.H. \& Rhoton Jr., A.L. 1975. Microsurgical anatomy of the sellar region. J. Neurosurg. 43(3): 288-298.

Russell, B.G. \& Kjaer, I. 1999. Postnatal structure of the sella turcica in Down Syndrome. Am. J.Med. Genet. 87(2): 183188

Scribante, A., Sfondrini, M.F., Cassani, M., Fraticelli, D., Beccari, S. \& Gandini, P. 2017. Sella turcica bridging and dental anomalies: Is there an association? Int. J. Paediatr. Dent. 27(6): 568-573

Shah,A.M., Bashir, U. \& Ilyas, T. 2011. The shape and size of the sella turcica in skeletal class I, II and III patients presenting at Islamic International Dental Hospital, Islamabad. Pakistan Oral \& Dental Journal 31(1): 104-110.

Shrestha, G.K., Pokharel, P.R., Gyawali, R., Bhattarai, B.\& Giri, J. 2018. The morphology and bridging of the sella turcica in adult orthodontic patients. BMC Oral Health 18(1): 45.

Silverman, F.N. 1957. Roentgen standards fo-size of the pituitary fossa from infancy through adolescence. Am. J. Roentgenol Radium Ther. Nucl. Med. 78(3): 451-460.

Smektala, T., Jedrzejewski, M., Szyndel, J., Sporniak-Tutak, K. \& Olszewski, R. 2014. Experimental and clinical assessment of three-dimensional cephalometry: A systematic review. $J$. Craniomaxillofac. Surg. 42(8): 1795-1801.

Yasa, Y., Ocak, A., Bayrakdar, I.S., Duman, S.B. \& Gumussoy, I. 2017. Morphometric analysis of sella turcica using cone beam computed tomography. J. Craniofac. Surg. 28(1): e70-e74.

Mohd Zambri Mohamed Makhbul*

Orthodontic Unit

Klinik Pergigian Cahaya Suria

Banguan Pudu Sentral

Jalan Pudu, Kuala Lumpur, Federal Territory

Malaysia

Wan Nurazreena Wan Hassan

Department of Paediatric Dentistry and Orthodontics

\& Clinical Craniofacial Dentistry Research Group

Faculty of Dentistry

University of Malaya, 50603 Kuala Lumpur, Federal Territory Malaysia

Ricky Wing Kit Wong

Department of Dentistry and Maxillofacial Surgery

United Christian Hospital

Hong Kong SAR

China 
*Corresponding author; email: zambrimakhbul@gmail.com

Received: 9 February 2019

Accepted: 16 May 2019 